II. The Fault-slip Velocity and Acceleration, J. Phys. Earth, 22, 383-394.

大中康誉，1975，弾性反撥モデルに基く地震の物理 的基礎, 地震研究所彙報, 50, 187-208.

OHnakA. M., 1976, A Physical Basis for Earthquakes Based on the Elastic Rebound Model, Bull. Seism. Soc. Amer., 66, 433-451.

第 29 卷 $(1976)$ 第 2 輯

\section{マグマ貫入説理解に おける盲点}

科学技術庁

坂田正治

(昭和 51 年 8 月 16 日受理)

Blind Spots in Understanding of Magma Intrusion Models

Shoji SAKata

Science and Technology Agency

(Received August 16, 1976)

火山地帯に括将る土地隆起を説明するものとして マグマ貫入説がある. 地下深部からのマグマ供給に より，既存あるいは新しくできるマグマ溜り内部の 圧力が周囲より高くなることによつて，土地が押し 上げられて地盤が隆起するといら考えである，とこ ろでマグマ溜りとしては，Fig. 1A のように，内部 がすべてマグマで満たされた球状のものを考えるこ とがよくある.これらは本来計算の便利等のための 仮定である、しかし，マグマ貫入説といえば条件反 射的にAのよらなものを前提とすることが少からず ある、ここでは，地表変動を説明するマグマ溜りの 解としてAタイプは 1 つの特別な解でしかないこと を，マグマ充満度およびマグマ溜りの外形といら点 から明らかにしたい。

（1）マグマと周单の圧为差およびマグマ溜り外 側の形状が同じでさえあれば，自由表面の変形に関 する限り，Fig. 1B ならば，地表面を含む物体側にしてみれば，マグマ 溜りと接する境界での応力（圧力）条件が AとBで は全く同じだからである. Bでのマグマの体積はA に比べて非常に小心くてよい.

(2) Fig. 1C のようなもので，A そ注同じの

\section{Free Surface}

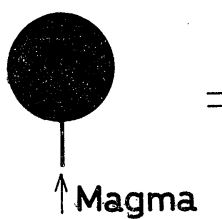

A

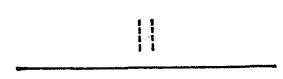

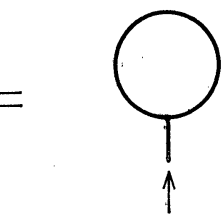

B

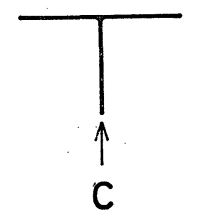

Fig. 1. Three types of magma intrusion models.

As far as the deformation of the free surface is concerned, B is completely equivalent to $\mathrm{A}$; and $\mathrm{C}$ is approximately equivalent to $\mathrm{A}$.

地表変動を説明できるものが存在することは自明で ある．この場合も，Cのマグマ体積は $\mathrm{A}$ に比べて非 常に小さい.

今， $\mathrm{B} や \mathrm{C}$ を 1 つの極端とすれば， $\mathrm{A}$ も 1 つの極 端である. Aの場合, 活火山の下のように既存のマグ マ溜りがある場合は別として，今まで固体であつた ものが溶けて、グマになる必要がある. 直径何 $\mathrm{km}$ もある巨大な物質が，短期間に全部溶けることはか なり困難であろう．一方， BやCの場合には，薄い 間隙をわずかの体積のマグマが満たすだけでよいの であるから，むしろAよりもありそらな気がする.

隆起に伴なら地学現象を説明しようとマグマ貫入 説を採用するとき，はじめからA型のみだと思いこ 及，熱や地磁気变化の計算が現実と合わないからと いつて，すぐマグマ貫入説を放棄する必要はない。 B型やC 型，あるい梳それらと $\mathrm{A}$ 型の中間型につい ても考えてみる必要がある， B 型やC 型の場合，極 端にいえば,マグマの量は“無限小”でもよいので ある。 